\title{
Creative thinking learning of physical education: Can be enhanced using discovery learning model?
}

\author{
Dupri* $^{\circledR}$, Novia Nazirun ${ }^{\mathbb{1}}$, Oki Candra ${ }^{\mathbb{1}}$ \\ Universitas Islam Riau, Indonesia
}

Received: 11 October 2020; Accepted 14 December 2020; Published 06 January 2021

Ed 2021; 6(1): 29-36

\begin{abstract}
The teacher-centered mindset and teaching methods are still teacher-centered, closing the space toward students to develop their creative thinking abilities. This study aims to determine the thinking skills of students in physical education learning using discovery learning models. This study used a quasi-experiment method and a pretest and posttest control group design. The research sample was obtained by means of random cluster sampling with a sample amount of 70 people. The instrument that used to measure students' creative thinking skills used the Torrance Test of Creative Thinking (TTCT) which before be tested, it has conducted the validity and reliability. The $t$ test was used as the analysis of this study. Discovery learning model is proven to be able to develop students' creative thinking skills when learning physical education. This is proven by the sig value. 0,000 so the discovery learning model in physical education learning will be able to develop creative thinking on students. This learning model must be applied in various fields of education. Research on the same topic should be carried out in the future, with the variability of different educational levels of subjects or educational institutional settings.
\end{abstract}

Keywords: Creative thinking; discovery learning; physical education

d

https://doi.org/10.25299/sportarea.2021.vol6(1).5690

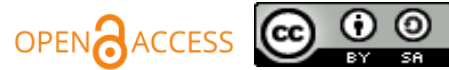

Copyright (C) 2021 Dupri, Novia Nazirun, Oki Candra

Corresponding author: Dupri, Physical Education Health and Recreation, Universitas Islam Riau, Pekanbaru, Riau, Indonesia

Email: dupri@edu.uir.ac.id

How To Cite: Dupri., Nazirun, N., \& Candra, O. (2021). Creative thinking learning of physical education: Can be enhanced using discovery learning model?. Journal Sport Area, 6(1), 29-36. https://doi.org/10.25299/sportarea.2021.vol6(1).5690

\section{INTRODUCTION}

Challenge in the future orders us to ba able skillful in several abilities ans skills in life. There are three main aspects in $21^{\text {st }}$ century, those are: learning and innovation skills, life and career skills and digital literacy (Trilling \& Fade, 2009). Critical thinking, creative thingking, communication and collaboration are four indicators that sign learning and innovation skill that should be owned (Dupri, Nazirun, \& Risma, 2019).

Critical thingking and creative thinking are the most valuable skills because one of high level skill (Fatmawati, Zubaidah, Mahanal, \& Sutopo, 2019), but this skill does not develop well on students to face problem in both of in learning and daily life (Hanifah, Subiyantoro, \& Muzzazinah, 2020). Creative thinking becomes important because the beginning step for person who can do critical thinking, that will make someone can give idea, insight and new breakthrough. For the next Nurjan (2018) also explains creative thinking is mental activity to develop or to find original ideas, aesthetic, constructive that relate with concept view and emphasize on intuitive and rasional thinking aspect. Thus by having the creative thinking skill, we expect it will not be difficult to face challenge and to compete in society era for the next. 
Globalization world nowadays, creativity is essential element in construction and basic capital in building better quality of in a country (Bereczki, 2016). School in giving edication has roles in developing kid's creativity skill. A teacher will be facilitator in reaching kid's creative thinking skill. Reality in field on learning of physical education at school, we can see now that students in creative thingking, that is students still less active in studying, teacher dominates in learning process so students tend be passive, teacher tends to demonstrate learning directly toward students. Relating with that Junaidi (2016) states learning of physical education nowadays students are more accepting information, not brave to ask even students often feel bored in following learning and end on the lack of active and creative students in learning process. Therefore stimulation toward students in developing students' creative thingking will not be created. Bacanli, Dombayci, Demir, and Tarhan (2011) states that there are eight things that students should have in developing creative thinking. It can be devided be two groups those are four cognitive elements and four affective elements, that consist of flexibility, fluent thinking, elaboration, curiosity, originality, complexity, imagination and taking of risk. Another thing that can support to think creative such what Bacanli et al., (2011) states that is someone who has amplicative thinking, loves with challenge thinking and also ideative.

Setiawan, Juliantine, and Komarudin (2018) show that learning of based problem model has more effective impact and can be applied by teachers of physical education in developing students' creativity. Another side, Ladjar, Juliantine, Mulyana, and Berliana (2018) states discovery learning model is a model that also categorized to scientific learning model and also suitable to develop students' creative thingking skill that has high IQ (Intellectual Quotion). Whereas creative thinking skill is not only a need from who has high IQ but also for all of us, therefore how we can develop through this discovery learning. Furthermore Ladjar, et al., (2018) also states that students are active independently searching, finding out and getting understanding toward material given that based from feedback given so expected this models can really increase students' creative thinking skill. Based on problem above researcher feels important to conduct this research because there is demand of human resources that can compete in field working, generally in education world and specifically in physical education learning. This research aims: (1) to produce physical education learning based discovery learning that can enhance creative thinking skill; (2) to know the increasing creative thinking skill through learning discovery on physical education learning.

Discovery learning is braces process to make an effort in conducting motor skill as often as possible with hypothesis basic that expressed and make modification based on result of feedback (Raab, Masters, Maxwell, Arnold, Schlapkohl, \& Poolton, 2011). Alfieri, Brooks, Aldrich, and Tenenbaum (2011) express that discovery learning happens when students are not given information target or conceptual understanding and should find out it independently and only with material provided. Discovery learning can be difined as discovery of concept from data sequence and information that gained from result of observation (Raab et al., 2011).

Students' creativity can grow and develop well, if family and social environment, especially school environment also support them in expressing their creativity (Zimmerman, 2009). Creativity is result of process of interaction between individu with environment. Someone can be influented by environment wherever they stand. It means that creativity that someone owns can develop based on environment where they stand (Setiawan et al., 2018). Related with the explanation, one of effort to guide students' creativity development is through physical education learning in school environment (Cheung, 2010). Nevertheless, unfortunately research about creativity is still seldom be conducted in education world, especially physical education Konstantinidou, Michalopoulou, Agelousis, \& Kourtesis, 2013). Cheung (2016) states creative practice is complex, changes and develops, so it needs there is discussion more in agreement of creative pedagogic culture and suggest implication for research, practice and practicioner research in the future in another education context. Thus in this research it proves that discovery learning can increase students' creative thinking skill through physical education. Since there is no previous research that proves the use of this model in developing creative thinking. As like elaborated above, it also needs to be seen further about creative thinking development on physical education learning.

In giving further understanding about creative thinking, Lipman states that there are four main aspects about creativity on the model (Bacanli et al., 2011). Those are imaginative, holistic, inventive and 
generative. Lipman gives description about process of creativity that should be owned by someone, those are: Productivity: able to create one product; Imaginative: creative people create new things with their imagination; Independence: dependence on something is the worst barrier for creativity. Creativity needs freedom; Experiment: creative people usually test their solution such they find; Holism: creativity generally means intact and complete solution; Expression: creativity shows theirselves; Transcendence; creative people pass theirselves, beyond present situation; Surprise: creativity usually creates product and strange cause; Amazing: creative people like nature, their product makes people surrounding amazed; Generativity: creativity appears and suggests several solutions. Creativity means many solution ways. Whereas in this research, the creative meant is students' skill creating new thing in conducting, finding out new thing and growing activeness in studying of physical education, so this research becomes essential to be conducted.

Nonetheless in the last decade, it is lack of students' creative research in physical education, mainly in country that many see creativity in other subjects. Research that has been done on physical education, looking the playing learning interest in developing students' creativity (Wibowo, 2010; Priyanto, 2014), whereas Ladjar et al., (2018) see students' creative thinking through problem base learning by looking from students' intellectual skill aspect. Several researches have discussed impact from various factors on creative teaching of physical education teachers from multilevel perspective. Nonetheless, research about physical education learning by using discovery learning model, there has no been found and seen directly that students' creative skill one by one opens generally and here is place of modification from research done. This research will affect toward providing of creative learning with creative students and enhancing students' creativity in studying and daily life. Beside researchers also look how school role in developing students' creative skill.

\section{METHODS}

Research method selected for this research is quasi experiment with Pretest and Posttest Control Group Design. This research will be conducted in SMA N 1 Teluk Kuantan. Population in this research is students of SMA N 1 Teluk Kuantan X grade amount 321 students. The taking of sample in this research is cluster random sampling so sample in this research amount 70 students that consist of X IPA I grade (experiment) and X IPA III grade (control). Instrument used to measure students' creative thinking by using Test of Creatifve Thingking (TTCT) (Kim, 2011). This instrument is questioner related creative thinking consist of 5 indicators, those are 1) Fluent thinking, 2) Elaboration, 3) Flexible thinking, 4) Conclusion, 5) Title abstractness. There are grid of this questioner can be seen on table 1 .

Table 1. Creative Thinking Questionnaire Grid

\section{Variable of Research Indicators}

\begin{tabular}{ll} 
& $\begin{array}{l}\text { Fluent thinking } \\
\text { skill }\end{array}$ \\
\cline { 2 - 2 } $\begin{array}{c}\text { Students' Creative } \\
\text { Thinking Skill }\end{array}$ & $\begin{array}{l}\text { Flexible thinking } \\
\text { skill }\end{array}$ \\
\cline { 2 - 2 } & $\begin{array}{l}\text { Original thinking } \\
\text { skill }\end{array}$ \\
\hline $\begin{array}{l}\text { Detailing thinking } \\
\text { skill }\end{array}$ \\
\hline
\end{tabular}

a) Come up with a lot of answers, ideas, problem solving and questions

b) Provide many ways or suggestions for doing things

c) Always think of more than one answer

a) Generating a variety of ideas, answers and questions

b) Can see a problem with different directions of thought

c) Able to change the way of approach or thinking

a) Be able to produce unique and new expressions

b) Able to make combinations unusual parts of parts or elements

a) Develop, add, enrich an idea

b) Able to detail the details of an object so that it becomes interesting

Before going to the field, research instrument will be conducted validity and reliability test that is based on counting result amount 32 items of test that stated valid and the reliability with value Cronbach's Alpha amount 0,845 . Before analysing of research toward data gained, first it will do normality and homogeneity test. T-test is used to do analysis from this research by using SPSS 22. 


\section{RESULT AND DISCUSSION}

Before conducting the collecting data to be analysed, this research gives action amount 8 meetings out of pre-test and post-test. This research conducts analysis by using T-test from result of pre-test and post test both of experiment group and control group. Based on result of analysis that conducted, it is found result of research such as on table 2 .

Table 2. Paired Samples Test of Creative Thinking

\begin{tabular}{ccccc}
\hline & Mean & T & Df & Sig. (2 tailed) \\
\hline Pretest- Posttest Discovery Learning & 88 & 8.956 & 35 & .000 \\
\hline Pretest- Posttest Konvensional & 73 & 6.432 & 35 & .112 \\
\hline
\end{tabular}

From result of Paired Samples Test that looks on table 2 above that value sig amount $0,000<\alpha=0.05$. This result proves that learning of physical education by using discovery learning model has significant influence. Toward the increase of students' creative thinking. The different thing happenes on physical education learning that conducted conventionally, it shows that it does not prove significantly increasing students' creative thinking skill.

Table 3. Independent Samples Test

\begin{tabular}{ccccc}
\hline F & Sig & T & Df & Sig. (2-tailed) \\
\hline 8.175 & .000 & 5.134 & 69 & .000 \\
\hline
\end{tabular}

Result of Independent Samples Test on table 3 above shows that discovery learning model and conventional model gain value sig amount $0,000<\alpha=0.05$ this means there is difference of students' creative skill through physical education learning between discovery learning model and conventional model. Creative thinking skill that appears through discovery learning model can create more effective learning from the sudents.

If we see table 1 , mean value of discovery learning amount 88 , whereas on conventional model amount 73 , this case can be defined that students' creative thinking skill on discovery learning model is better on conventional learning. The same result also is found by La djar et al., (2018) that discovery learning has difference toward creative thinking on students that has high intellectual quotion.

Table 4. Test of Students' Creative Thinking Skill

\begin{tabular}{|c|c|c|c|c|}
\hline \multirow{2}{*}{ Component } & \multicolumn{2}{|c|}{ Discovery Learning } & \multicolumn{2}{|c|}{ Conventional } \\
\hline & Pre-test & Post-test & Pre-test & Post-test \\
\hline Less creative & 10 & 3 & 6 & 2 \\
\hline Enough creative & 15 & 7 & 20 & 21 \\
\hline Creative & 10 & 20 & 9 & 11 \\
\hline Very creative & 0 & 5 & 0 & 1 \\
\hline $\mathrm{N}$ & 35 & 35 & 35 & 35 \\
\hline
\end{tabular}

From table above, we can see that creative thinking skill on students by doing physical education learning using discovery learning model there is the increase where in the previous who categorized in creative amount 10 only and after action becomes 20 people and who enough and less creative have decrease. Whereas on control class there is the increase of number on creative level it is 2 people and more on enough creative amount 21 people.

In this research, participants are dominated by young male students around 18 until 20 years old. Most of them come from region, and take IPA course and they are more than male. Although there is no proof that effectiveness of creativity learning depends on gender or age (Perry \& Karpova, 2017), research result possibly can not be generalized to another population.

Learning process that gives time to students to find out interesting game form in learning giving chance to students to think creative which this case is content of discovery learning. Not only that, the creative form of students also develops in the form of skills that appear when playing in the field to be able to get 
numbers, as also expressed by Wibowo (2010) that through games in physical education learning will develop social interaction skills, collaboration skills and developing creativity. through a game that is presented, because by playing new ideas will emerge from the results of thoughts for solving problems in a game and creating new things from a game.

Field findings show that students in the learning process took place asking the question "what if we do a pass over one of his feet in front of him, sir?". Question like this is one of the creative thinking process that has begun to appear in students. Then, with the feedback given by the teacher, it increases the enthusiasm of students to be able to solve problems that arise. As like what stated by Nurjan (2018) feedback is given as an encouragement to raise creativity, provide challenges in the form of problems and inspirational questions that will inspire children's curiosity. Identifying and solving problems can be accomplished through, for example, outdoors (volleyball games, basketball, football, badminton) and adventure activities, although we should not assume that problem solving by itself is sufficient, instead we allow children to take the responsibility of managing problems as well and not just being a passive recipient of the task. By doing things like this, it will foster students' creative thinking skills and materials can reach critical thinking. Putting forward creative pedagogy is important to improve students' creative development, namely through three interrelated elements of creative teaching, teaching for creativity and creative learning (Lin, 2011).

Research evidence shows that movement and creativity are closely related Konstantinidou et al., (2013) states that intervention programs have been implemented to promote children's creative potential through the movement, an inquiry into European school curricula that promote creativity establishes physical education among the most popular subjects in schools, in Greece, at least the last decade, children's motor creativity has been promoted through physical education curricula, especially in first grade. However, research that supports increased creativity in physical education is very limited, because it focuses more on evaluating children's motor responses. Around the world, although it is necessary to investigate, through implicit theory, teachers' perceptions of creativity and its promotion in various disciplines, it seems that this kind of research is still in its infancy. Turpin, Matthee, and Kruger (2015) found that the development of creative abilities involves more than just teaching creative techniques and the creativity can be indirectly nurtured in a number of ways.

If we see from point of view of motoric, Rachman (2006) concludes that motoric perceptual skill influences toward intellectual, social and emotional development. Motoric perceptual supports someone to explore cognitive in her/his environment, able to handle her/his body toward outside object and has the good movement quality. A creative playing environment is base of philosophy from learning form that can develop creativity on early age students (Priyanto, 2014). Several research shows that imaginative play can develop some skill, including creativity, memory development, collaboration, acceptance of vocabulary, friendship and self controlling. Rachman (2006) expresses creativity on students has developed since 4 years old, it can be seen on cerebellum structure that has reached $80 \%$. On this phase, motoric function starts developing and interacting with the environment. While the emotional-cognitive system develops through playing, imitating and reading of story. Whereas the higher quotient will develop if students are treated correctly by caring their emotional health.

Development of creative thinking skill on these students looks they are be more confident in uttering opinion with support and motivation from teacher, relating with it Dupri and Nazirun (2020) prove that giving positive feedback has good influence in developing students' self-esteem, self-esteem on students will be easy to think creative and develop well.

While learning process of motor is taking place, mostly students show their creative thinking process, this shows design of learning activity with discovery learning model making students be active. But, the limited experience in doing creative motor and the limited cognitiveabout teaching material cause them not confident to move by themselves. Implementing creative motor activity routinely will give opportunity to students to manifest their creative skill (Cheung, 2010). When stuents' creative experience is enriched, they can feel comfortable with their body and with confidence to express self through movement.

Impact from this research is not only able developing creative skill on students, but also giving impact to teachers for able preparing creative learning for creative studying in physical education. As like stated by 
Deng, Zheng, and Chen, (2020) for studying creative, it needs creative teacher in serving learning, this case can bee seen through teacher's personality. Beside school also has essential role in supporting success of creative learning, creative teaching in teaching and to make students be creative.

Skill in solving problem has essential role in teacher creative performance and physical education is very different than another education (Mancini \& Bonanno, 2020). This focuses on physical activity and has various characteristics, specialization and humanization. Beside developing motoric skill and someone's mental quotient, physical education teaching often uses collective activity to support positive personality and teenager social development. Therefore, in physical education teacher environment, if support of school can assist teacher's efficacy, it will be possibly condusive to support the extent of creative performance, the contrary if environment factor destructs teacher's efficacy so performance of creative teaching can be less. Therefore, environment factor of school can directly influence teacher's creativity or indirectly it can influence individual creativity performance. It means that efficacy possibly has connection effect between supporting of school and creative teaching performance. This case is another point of view in developing students' creative thinking skill in this research.

\section{CONCLUSION}

The research result finds that discovery learning model is able to increase creative thinking skill through physical education learning at school with value sig. 0,000. Therefor discovery learning becomes one of model that able to develop skill needed in pandemic periode that always conducts learning in long distance, beside that creative is skill that should be developed in society era 5.0 in the future. Key in increasing creativity is with creative teaching, teaching for creativity and creative learning. Although like that, researchers invite another researcher continuously finding out pattern of good learning model to develop students' character well. This learning model should be applied in various education side. Research with the same topic should be conducted in the future, with variability of subject education level or the setting of different education institution. There has no been difference yet from gender side and creative cognitive skill in looking students' creative thinking skill is something need to be discussed further.

\section{REFERENCES}

Alfieri, L., Brooks, P. J., Aldrich, N. J., \& Tenenbaum, H. R. (2011). Does Discovery-Based Instruction Enhance Learning? Journal of Educational Psychology, 103(1), 1-18. https://doi.org/10.1037/a0021017

Bacanli, H., Dombayci, M. A., Demir, M., \& Tarhan, S. (2011). Quadruple thinking: Creative thinking. Procedia - Social and Behavioral Sciences, 12, 536-544. https://doi.org/10.1016/j.sbspro.2011.02.065

Bereczki, E. O. (2016). Mapping creativity in the Hungarian National Core Curriculum: a content analysis of the overall statements of intent, curricular areas and education levels. Curriculum Journal, 27(3), 330-367. https://doi.org/10.1080/09585176.2015.1100546

Cheung, R. H. P. (2010). Designing movement activities to develop children's creativity in early childhood education. Early Child Development and Care, 180(3), 377-385. https://doi.org/10.1080/03004430801931196

Cheung, R. H. P. (2016). The challenge of developing creativity in a Chinese context: the effectiveness of adapting Western creative pedagogy to inform creative practice. Pedagogy, Culture and Society, 24(1), 141-160. https://doi.org/10.1080/14681366.2015.1087419 
Deng, Q., Zheng, B., \& Chen, J. (2020). The Relationship Between Personality Traits, Resilience, School Support, and Creative Teaching in Higher School Physical Education Teachers. Frontiers in Psychology, 11(September), 1-11. https://doi.org/10.3389/fpsyg.2020.568906

Dupri, D., \& Nazirun, N. (2020). The Effort to Develop Junior High School Students Self-Esteem Through Giving Positive Feedbacks. 21(Icsshpe 2019), 71-74. https://doi.org/10.2991/ahsr.k.200214.020

Dupri., Nazirun, N., \& Risma, N. (2019). Penerapan Model Problem Based Learning Untuk Meningkatkan Keterampilan Berpikir Kritis Pada Pendidikan Jasmani. Journal Sport Area, 4(2), 318. https://doi.org/10.25299/sportarea.2019.vol4(2).3760

Fatmawati, A., Zubaidah, S., Mahanal, S., \& Sutopo. (2019). Critical Thinking, Creative Thinking, and Learning Achievement: How They are Related. Journal of Physics: Conference Series, 1417(1). https://doi.org/10.1088/1742-6596/1417/1/012070

Hanifah, W., Subiyantoro, S., \& Muzzazinah. (2020). Creative Thinking Skills in Science Lessons in Elementary Schools. 397 (ICLIQE 2019), 870-875. https://doi.org/10.2991/assehr.k.200129.107

Junaidi, J. (2016). Pengaruh Gaya Mengajar Resiprokal Dalam Pembelajaran Permainan Bola Voli Terhadap Pengembangan Kreativitas Siswa. Jurnal Pendidikan Jasmani dan Olahraga, 1(1), 17. https://doi.org/10.17509/jpjo.v1i1.3660

Kim, K. H. (2011). The Creativity Crisis: The Decrease in Creative Thinking Scores on the Torrance Tests of Creative Thinking. Creativity Research Journal, 23(4), 285-295. https://doi.org/10.1080/10400419.2011.627805

Konstantinidou, E., Michalopoulou, M., Agelousis, N., \& Kourtesis, T. (2013). Primary Physical Education Perspective on Creativity: The Characteristics of the Creative Student and Their Creative Outcomes. International Journal of Humanities and Social Science, 3(3), 234-247. https://doi.org/10.1080/03004430.2013.818989

Ladjar, M. A. B., Juliantine, T., Mulyana, \& Berliana. (2018). Pengaruh Model Problem-Based Learning dan Discovery Learning serta Kecerdasan Intelektual terhadap Berpikir Kreatif. Jurnal Pendidikan Jasmani dan Olahraga, 3(1), 22. https://doi.org/10.17509/jpjo.v3i1.9837

Lin, Y.-S. (2011). Fostering Creativity through Education - A Conceptual Framework of Creative Pedagogy. Creative Education, 02(03), 149-155. https://doi.org/10.4236/ce.2011.23021

Mancini, A. D., \& Bonanno, G. A. (2009). Predictors and parameters of resilience to loss: Toward an individual differences model. Journal of Personality,77(6), 1805-1832. 1805-1832. https://doi.org/10.1111/j.1467-6494.2009.00601.x

Nurjan, S. (2018). Pengembangan Berpikir Kreatif. Al-Asasiyyah: Journal Basic of Education, 3(01), 14-18. https://doi.org/10.24269/AJBE.V3I1.1302

Perry, A., \& Karpova, E. (2017). Efficacy of teaching creative thinking skills: A comparison of multiple creativity assessments. Thinking Skills and Creativity, 24, 118-126. https://doi.org/10.1016/j.tsc.2017.02.017 
Priyanto, A. (2014). Pengembangan Kreativitas Pada Anak Usia Dini Melalui Aktivitas Bermain. Jurnal Ilmiah Guru Caraka Olah Pikir Edukatif, 18(2), 41-47.

Raab, M., Masters, R. S. W., Maxwell, J., Arnold, A., Schlapkohl, N., \& Poolton, J. (2011). Discovery learning in sports: Implicit or explicit processes? International Journal of Sport and Exercise Psychology, 7(4), 413-430. https://doi.org/10.1080/1612197X.2009.9671917

Rachman, H. A. (2006). Membangun kembali jembatan antara kreativitas dan pendidikan jasmani. Jurnal Pendidikan Jasmani Indonesia, 5(1), 21-32. https://doi.org/10.21831/jpji.v5i1.6216

Setiawan, E., Juliantine, T., \& Komarudin, K. (2017). Development creativity students through problem based learning model in physical education in reviewed of adversity quotient. In 2nd International Conference on Sports Science, Health and Physical Education (pp. 611-613). https://doi.org/10.5220/0007066606110613

Trilling, B., \& Fade, C. (2009). 21st Century Skill Learning For Life in Our Times. San Francisco: JosseyBass.

Turpin, M., Matthee, M., \& Kruger, A. (2015). The teaching of creativity in information systems programmes at South African higher education institutions. African Journal of Research in Mathematics, Science and Technology Education, 19(3), 278-288. https://doi.org/10.1080/10288457.2015.1104838

Wibowo, Y. A. (2010). Bermain dan Kreativitas dalam Pembelajaran Pendidikan Jasmani. Jurnal Pendidikan Jasmani Indonesia, 7(2), 1-15.

Zimmerman, E. (2009). Reconceptualizing the Role of Creativity in Art Education Theory and Practice. Studies in Art Education, 50(4), 382-399. https://doi.org/10.1080/00393541.2009.11518783 